\title{
Anatexis and fluid flow recorded by kyanite-garnet metapelitic migmatite from Gurskøy, Western Gneiss Region (Norway): a hot start for crustal subduction
}

\author{
BRUNA B. CARVALHO ${ }^{1}$, MARTIN HAND ${ }^{2}$, RENÉE \\ TAMBLYN $^{2}$, SAMANTHA NICOLE MARCH ${ }^{2}$, CHRIS \\ CLARK $^{3}$ AND MATTIA GILIO ${ }^{4}$ \\ ${ }^{1}$ Università degli studi di Padova \\ ${ }^{2}$ The University of Adelaide \\ ${ }^{3}$ Curtin University \\ ${ }^{4}$ University of Pavia \\ Presenting Author: bruna.borgescarvalho@unipd.it
}

High to ultra-high pressure eclogite facies rocks are well preserved in the Western Gneiss Region (WGR - Norway) and doubtlessly reflect the subduction of crustal fragments to mantle depths. Despite petrological and geodynamic aspects of the area have been thoroughly investigated, much about anatexis and fluid flow can still be learned.

In this contribution we examine a kyanite-garnet stromatic metatexite from Gurskøy, WGR. Garnet (up to $4 \mathrm{~mm}$ ) in these rocks is zoned, almandine-rich but with variable proportions of grossular and pyrope. Despite the intensity of metamorphism, residual prograde zoning is preserved. A preliminary Lu-Hf dating has revealed that these garnets grew during the Caledonian event.

The most remarkable feature of those garnets is the presence of two types of multiphase inclusions. Type 1 inclusions (50-200 $\mu \mathrm{m})$ are composed of quartz and feldspars, usually have radial cracks, and occur distributed in the core of the garnets together with single crystal inclusions of quartz and rutile. Type 2 inclusions $(2-5 \mu \mathrm{m})$ are multiphase fluid inclusions located at the mantles and rims of the garnet. These inclusions contain a pure high density (up to $0.99 \mathrm{~g} . \mathrm{cm}^{-3}$ ) $\mathrm{CO}_{2}$ fluid which coexists with carbonates, pyrophyllite, rutile and, less frequently, graphite. Detailed micro-Raman investigation has revealed that the carbonate assemblage contains dolomite (strong Raman peaks at 1096 and $\left.299 \mathrm{~cm}^{-1}\right)$, magnesite (1090, 735 and $212 \mathrm{~cm}^{-1}$ ) and aragonite $\left(1084,710\right.$ and $\left.209 \mathrm{~cm}^{-1}\right)$.

We envisage that both types of inclusions were trapped during the growth of garnet on the prograde path; type 1 inclusions are likely former melt inclusions, whereas, type 2 inclusions are evidence of immiscibility in a C-O-H system. Entrapment of probable melt during the early stages of garnet growth points to the existence of a hot crustal slab in the early stages of collision between Baltica and Laurentia. With burial into the mantle carbonates may have precipitated directly from fluids released as prograde melts crystallised during crustal isotherm advection into the mantle. The presence of aragonite suggests carbonate precipitation from the fluid happened at minimum pressure conditions of c. 1.8-2.0 GPa, and was preserved during ensuing high-temperature exhumation into sillimanite-stable crustal depths. 